\title{
The influence of low temperatures on the incidence of sugary disease on sorghum
}

\author{
Influência de baixas temperaturas na incidência da doença-açucarada em sorgo
}

\author{
Amauri Bogo ${ }^{1}$ Ricardo Trezi Casa ${ }^{1}$ Luis Sangoi ${ }^{1}$ Paulo Tarcísio Domatos Borba ${ }^{2}$
}

\begin{abstract}
The relationship between pre-flowering climatic conditions and sugary disease incidence was quantified in grain and forage sorghum genotypes at two sowing periods (mid November and mid December). The trials were carried out over the 2001/02 and 2002/03 growing seasons, in Lages, Santa Catarina State. Four commercial male-fertile sorghum hybrids (BR 600-forrage, BR 700-grain, BR 701-forage/silage and BR 800-forage) and one male-sterile inbred line (BR 001A) were evaluated. When each genotype reached the flowering stage, 50 panicles were marked and sprayed with a suspension of Claviceps africana (1,000 spores $\left.m L^{-1}\right)$. Air temperature, humidity and rainfall were recorded through out the growing cycle. Low temperatures three to four weeks prior to flowering, increased susceptibility. At both sowing periods, average night temperatures lower than $15^{\circ} \mathrm{C}$ during the critical period of preflowering turned the fertile hybrids as susceptible as the malesterile inbred to ergot infection. The tested hybrids differed in their ability to tolerate pre-flowering cold stress. Seed set in uninoculated heads under pollination bags was also reduced, suggesting that increased susceptibility to sugary disease was the result of low temperature induced sterility.
\end{abstract}

Key words: Sorghum bicolor, Claviceps africana, ergot, hybrid, male-sterility, environment.

\section{RESUMO}

A relação entre as condições climáticas no préflorescimento e a incidência da doença açucarada em sorgo foi quantificada, em duas épocas de semeadura (metade de novembro e metade de dezembro) durante os anos agrícolas de 2001/02 e 2002/03. Experimentos foram conduzidos com quatro híbridos férteis (BR 600-forragem, BR 700-grão/ silagem, BR 701-forragem/silagem and BR 800-corte/pastejo) e uma linhagem macho-estéril (BR 001-A) de sorgo granífero e forrageiro. Quando cada genótipo atingiu o florescimento, 50 panículas foram marcadas e aspergidas com uma suspensão de Claviceps africana (1.000 esporos $\left.m L^{-1}\right)$. A temperatura e umidade relativa do ar e a precipitação foram registradas durante todo o ciclo da cultura. Baixas temperaturas noturnas entre três a quatro semanas que antecederam o florescimento, aumentaram a susceptibilidade à doença açucarada. Nas duas épocas de semeadura, temperaturas médias noturnas abaixo de $15^{\circ} \mathrm{C}$ durante o período crítico de pré-florescimento induziram os híbridos férteis a serem tão suscetíveis quanto o genótipo macho-estéril à doença açucarada. Os híbridos testados diferiram na tolerância ao estresse causado pelo frio na fase de pré-florescimento. A taxa de formação das sementes em panículas não inoculadas cobertas por saco polinizador também foi reduzida, sugerindo que o aumento da susceptibilidade à doença decorreu da influência da baixa temperatura, induzindo à esterilidade.

Palavras-chave: Sorghum bicolor, Claviceps africana, ergot, híbrido, macho-esterilidade, ambiente.

\section{INTRODUCTION}

The sorghum (Sorghum bicolor L. Moench) sugary disease was first reported in Brazil by REIS et al. (1996) in the states of São Paulo, Minas Gerais and Goiás. Although the pathogen has been generally known by its imperfect designation (Sphacelia sorghi McRae), the disease is caused in the country by the perfect form Claviceps africana Frederickson, Mantle and De Milliano (FREDERICKSON et al., 1991). It is a chronic problem among the A-inbred lines (male-sterile sorghums) used to produce F1 hybrids in many breeding programs, reducing seed yield and quality.

${ }^{1}$ Departamento de Fitotecnia, Centro de Ciências Agroveterinárias (CAV), Universidade do Estado de Santa Catarina (UDESC), Av. Luiz de Camões, 2090, 88520-000, Lages-SC, Brasil. E-mail: a2ab@cav.udesc.br.

${ }^{2}$ Curso de Agronomia, UDESC, Lages, SC,Brasil. 
Pollination and fertilization are primary factors affecting ergot development in cereals (MCLAREN \& WEHNER, 1992). In pearl millet, pollination prevents infection by $\boldsymbol{C}$. fusiformis (LOVELESS, 1967) or restricts hyphae from reaching the ovary (THAKUR \& WILLIAMS, 1980, WILLINGALE et al., 1986). Susceptibility of millet genotypes to ergot is inversely related to the duration of protogeny while pollen availability, as determined by pollen donor:female ratios in breeding plots, affects ergot incidence (THAKUR \& RAO, 1983). WATKINS \& LITTLEFIELD (1976) reported an increase in ergot of wheat at low temperatures. They suggested that anthers are sensitive to low temperatures, which delays pollen-shed, and forces the ovaries to remain unfertilized for longer periods, favoring ergot infection.

Pre-flowering cold stress can induce male sterility in sorghum grain with the degree of sterility being linearly related to night temperatures from the flag leaf ligule emergence until the flag leaf sheath elongation up to approximately $20 \mathrm{~cm}$. The incidence of sorghum sugary disease can also be related to the average daily maximum temperature during the four days following pollen shed commencement (MCLAREN \& WEHNER, 1992)

Understanding the impact of environmental conditions on the incidence of sorghum sugary disease is important to prevent serious economic problems especially in hybrid seed production. This study was carried out to determine the relationship between two sowing periods (mid November and mid December) and predisposition to sugary disease of male-fertile and male-sterile sorghum genotypes grown in southern Brazil.

\section{MATERIAL AND METHODS}

Sugary disease development in male-fertile and male-sterile genotypes was evaluated. Five genotypes were tested: four male-fertile commercial hybrids: BR 600-forage, BR 700-grain, BR 701-forage/ silage and BR 800-forage; and one male-sterile inbred line: BR 001-A. The experiments were planted in Lages, SC, at two sowing periods (mid November and mid December) during the 2001/02 and 2002/03 growing seasons.

Each plot (genotype) was sown in $2.5 \mathrm{~m}$ line at $1.0 \mathrm{~m}$ intervals between rows in an entirely randomized manner directly into the field soil (Haplumbrept) with four repetitions. Plots were maintained free of weeds and insects until flowering and irrigation was applied as required.

Termohygrographs were placed at the experimental site during each season to monitor maximum and minimum air temperatures. Groups of 50 plants of each genotype were weekly labeled at flowering, recording the date of stigma emergence in male-sterile and pollen shed in male-fertile plants, respectively. Panicles of marked plants were sprayed with a water suspension of $\boldsymbol{C}$. africana (nearly 1,000 spores $\mathrm{mL}^{-1}$ ) until run-off. During the 2001/02 growing season, 50 non inoculated panicles of male-fertile genotypes were covered with pollination bags at the beginning of pollen shed to determine the percentage of seed formation at grain maturity (number of seed by panicle).

At the soft dough stage of grain development, infected florets on labeled panicles were recorded and the mean percentage of infected florets was determined for each genotype at the different flowering dates according to the two sowing periods. As sugary disease development is sensitive to climatic conditions during host infection and incubation (MCLAREN \& WEHNER, 1990 and 1992), it is more frequent and important in male sterile genotypes. Therefore, the disease incidence on the male-sterile inbred line (BR 001-A) was regarded as a measure of the sugary disease potential associated with climatic variability in each flowering date (mid November and mid December). The difference between the disease incidence in the male-sterile inbred line and the malefertile genotypes was assumed to be a measure of the role of viable pollen in reducing susceptibility to the disease. This was indexed as a male-fertile:male-sterile sugary disease incidence ratio (F:S ratio). Correlation and regression analyses were performed to determine the relationship between cold stress weekly before flowering and disease incidence.

\section{RESULTS AND DISCUSSION}

The F:S disease incidence ratio ranged from 0.38 to 0.79 for the first and from 0.44 to 0.92 for the second sowing periods, during the 2001/02 growing season. Such ratios varied from 0.41 to 0.82 and 0.44 to 0.88 for the first and second sowing periods during the 2002/03 growing season, respectively (Table 1 ). This was attributed to the cooler conditions affecting the flowering pattern and the pollination efficacy of sorghum genotypes. The percentage of infected florets during both periods of sowing and seasons varied from 68 to $94 \%$ (Table 1), showing that all hybrids tested are very susceptible to the sugary disease.

Correlation between the F:S ratio for each genotype and all possible combinations of minimum temperature for the 30-day period preceding flowering showed the highest values for the period of 20-25 days prior to pollen shed in BR $600(r=0.82)$ and BR $800(r=$ 
Table 1 - Percentage of infected sorghum genotypes florets by Claviceps africana and F:S ratio of sugary disease incidence variation for two sowing period (mid November and mid December) during the 2001/02 and 2002/03 seasons.

$$
\text { 2001/02 growing season }
$$

2002/03 growing season

\begin{tabular}{|c|c|c|c|c|c|c|c|c|}
\hline \multirow[t]{2}{*}{ genotypes } & \multicolumn{2}{|c|}{ 1st sowing period } & \multicolumn{2}{|c|}{ 2nd sowing period } & \multicolumn{2}{|c|}{ 1st sowing period } & \multicolumn{2}{|c|}{ 2nd sowing period } \\
\hline & $\begin{array}{l}\text { infected florets } \\
\text { (\%) }\end{array}$ & $\begin{array}{l}\mathrm{F}: \mathrm{S} \text { ratio } \\
\text { variation }\end{array}$ & $\begin{array}{l}\text { infected florets } \\
\text { (\%) }\end{array}$ & $\begin{array}{l}\mathrm{F}: \mathrm{S} \text { ratio } \\
\text { variation }\end{array}$ & $\begin{array}{l}\text { infected florets } \\
\text { (\%) }\end{array}$ & $\begin{array}{l}\mathrm{F}: \mathrm{S} \text { ratio } \\
\text { variation }\end{array}$ & $\begin{array}{l}\text { infected florets } \\
\text { (\%) }\end{array}$ & $\begin{array}{l}\mathrm{F}: \mathrm{S} \text { ratio } \\
\text { variation }\end{array}$ \\
\hline BR 600 & 71.0 & $0.41-0.75$ & 77.0 & $0.46-0.88$ & 74.0 & $0.41-0.79$ & 78.0 & $0.45-0.88$ \\
\hline BR 700 & 75.0 & $0.40-0.79$ & 78.0 & $0.48-0.90$ & 77.0 & $0.42-0.82$ & 75.0 & 0.44-0.85 \\
\hline BR 701 & 73.0 & $0.39-0.77$ & 78.0 & $0.44-0.89$ & 75.0 & $0.41-0.80$ & 77.0 & $0.46-0.87$ \\
\hline BR 800 & 68.0 & $0.38-0.72$ & 80.0 & $0.46-0.92$ & 77.0 & $0.43-0.82$ & 75.0 & $0.45-0.85$ \\
\hline BR 001-A & 94.0 & & 87.0 & & 93.0 & & 88.0 & \\
\hline
\end{tabular}

0.87), and days 22-28 in BR $700(\mathrm{r}=0.90)$ and BR 701 ( $\mathrm{r}$ $=0.88$ ) for the first period of sowing. When sorghum was sown in mid December, days 19-24 in BR 600 ( $\mathrm{r}=$ $0.84)$ and BR $700(\mathrm{r}=0.89)$ and days 23-27 in BR $701(\mathrm{r}$ $=0.85)$ and BR $800(\mathrm{r}=0.84)$ presented the highest correlation values.

The use of mean minimum air temperature over these periods as an independent variable in regression analysis showed that this variable accounted for 81 to $91 \%$ of the variation in the F:S ratio in the first sowing period (Figure $1 \mathrm{~A}$ ) and 74 to $80 \%$ in the second sowing period (Figure $1 \mathrm{~B}$ ).

The F:S ratios for the BR 700 and BR 600 hybrids were particularly temperature-sensitive, with linear decreases been recorded from 19 to $12^{\circ} \mathrm{C}$ for the first period of sowing (Figure 1A) and 20 to $15^{\circ} \mathrm{C}$ for the second period of sowing (Figure 1B).

The regression analysis showed the BR 701 and BR 800 hybrids were more temperature tolerant with an increase in the $\mathrm{F}: \mathrm{S}$ ratio occurring approximately at temperature $<15^{\circ} \mathrm{C}$ for the first period of sowing and $<17^{\circ} \mathrm{C}$ for the second period of sowing. These tendency can be visualized in Figure 1.

Seed formation under pollination bags during the 2001/02 season ranged from 89 to $97 \%$ at the first period of sowing and 91 to $96 \%$ for the second period of sowing (Table 2). Seed formation was associated with pre-flowering cold stress over the same period, with hybrids BR 700 and BR $800, r=0.85$ and 0.87 for the first (Figure $2 \mathrm{~A}$ ) and $\mathrm{r}=0.84$ and 0.86 for the second sowing period (Figure $2 \mathrm{~B}$ ) being more sensitive than hybrids BR 600 and BR 701, $r=0.81$ and 0.80 for the first (Figure 2A), and $r=0.82$ and 0.80 , for the second sowing period (Figure 2B), respectively, inducing reduction of pollen viability and consequently seed formation.

There was a strong negative linear relationship between the incidence of sugary disease and the percentage of seed formation, considering the average of five genotypes tested in the experiments. Each $10 \%$ of decrease in seed formation corresponded to a $6.5 \%$ increase on the disease incidence (Figure 3).

The occurrence of sugary disease on sorghum genotypes under artificial and natural disease pressure in southern Brazil illustrates how readily this pathogen can spread in the field. It also raises the possibility that first gaping florets at night, giving access to a few airborne secondary conidia as inoculum, may become infected before pollination because the large amount of airborne inoculum becomes concentrated later in the hours that follow.

Sugary disease in cereals develops from infection of unfertilized ovaries, primarily via the stigmas whereas pollination of stigmas is the primary factor that restricts infection of florets by $\boldsymbol{S}$. sorghi (MCLAREN \& WEHNER, 1992; FREDERICKSON at al., 1994; BOGO, 2001). The speed of pollination and fertilization has critical importance to prevent sugary disease epidemic. The reduction in the rate of pollination or pollen viability increases sugary disease susceptibility in male-fertile hybrids.

The use of the F:S ratio as a sugary disease evaluation criterion in the present study was based on the assumption that an infection frequency on malefertile hybrid equivalent to male-sterile hybrid ( $\mathrm{F}: \mathrm{S}=1$ ) for a specific set of climatic variables was the result of a total absence of pollination. Variation in the F:S ratio thus indicated various pollination - infection frequency interactions. The strong correlation between seed formation and the incidence of sugary disease in the present study suggests that this assumption was valid. The only trait that promotes growth of a particular grass host free from sugary disease is an efficient pollination/ fertilization, constituting a disease escape mechanism. However, further search for intrinsic gynoecial resistance to sugary disease in sorghum must be sought 

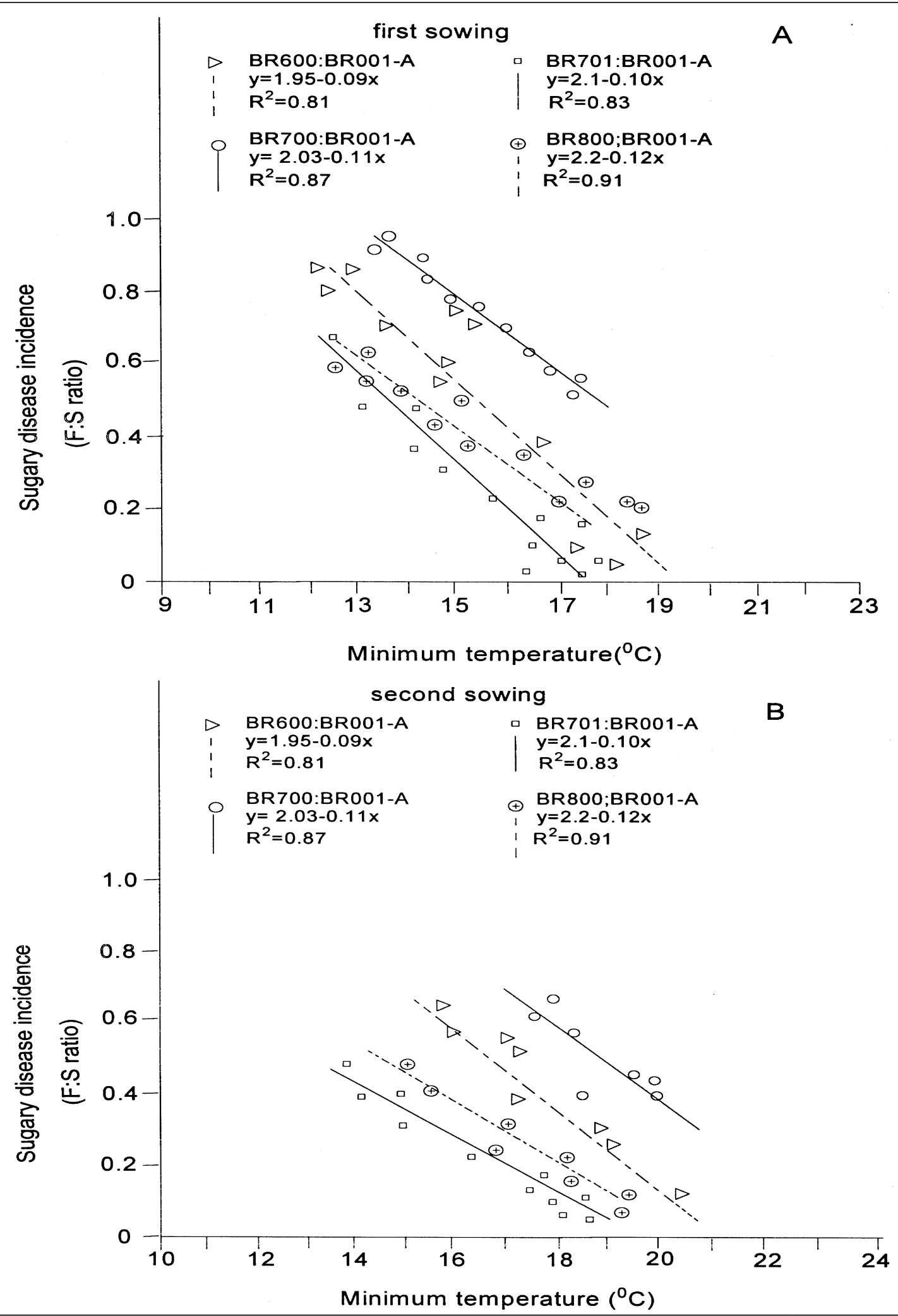

Figure 1 - Relationship between mean minimum temperature (20-25 days prior to pollen shed in BR 600 and BR 800 and 21-27 days in BR 700 and BR 701 sorghum hydrids) and male fertile:male-sterile sugary disease incidence ratio in first (A) and the second period of sowing (B) during 2001/02 and 2002/03 growing seasons.

Ciência Rural, v.36, n.2, mar-abr, 2006. 


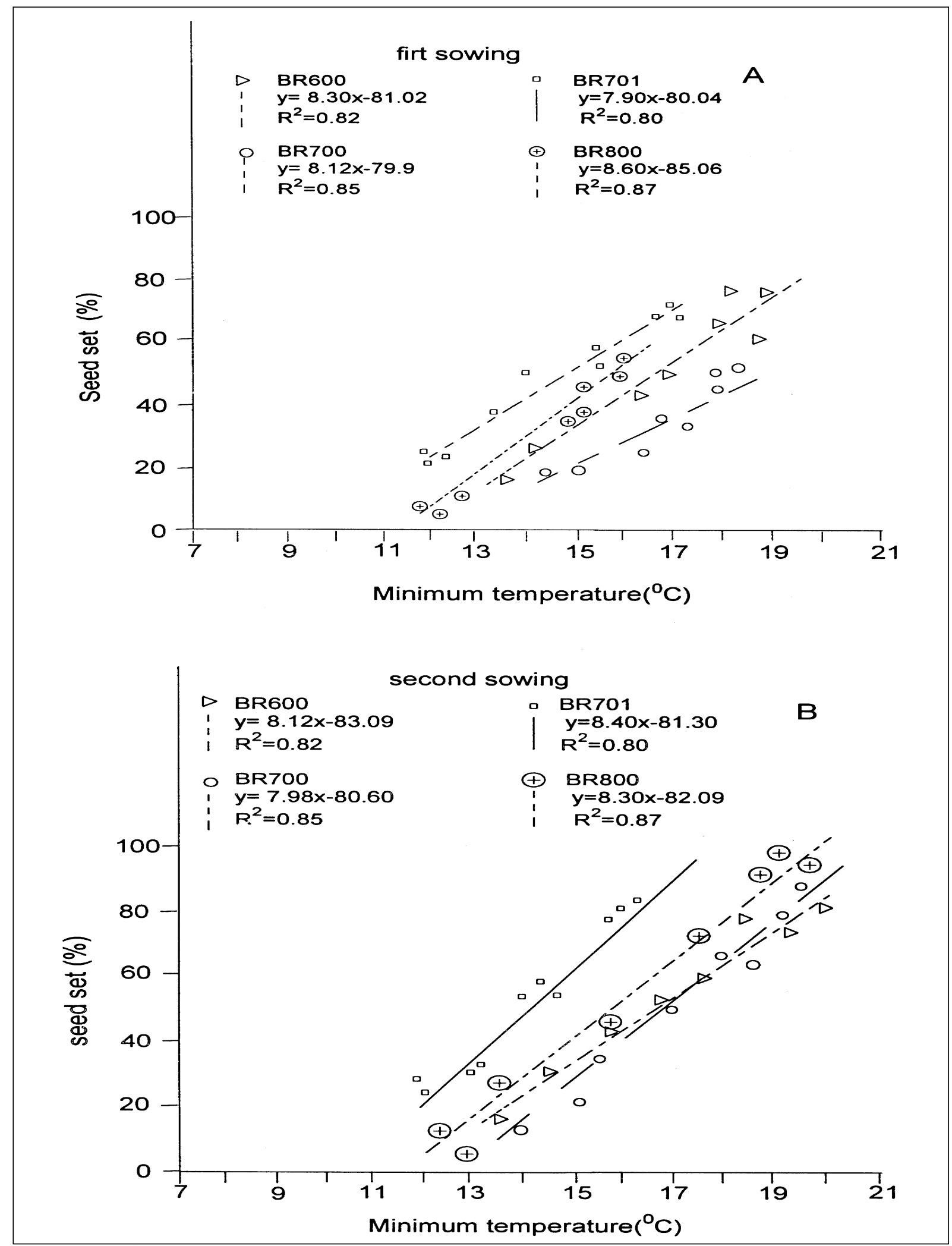

Figure 2 - Relationship between mean minimum temperature (20-24 days prior to pollen shed in BR 600 and BR 800 and 21-27 days in BR 700 and BR 701 sorghum hybrids) and seed set in the first (A) and second period of sowing (B) during the 2001/02 growing season. 


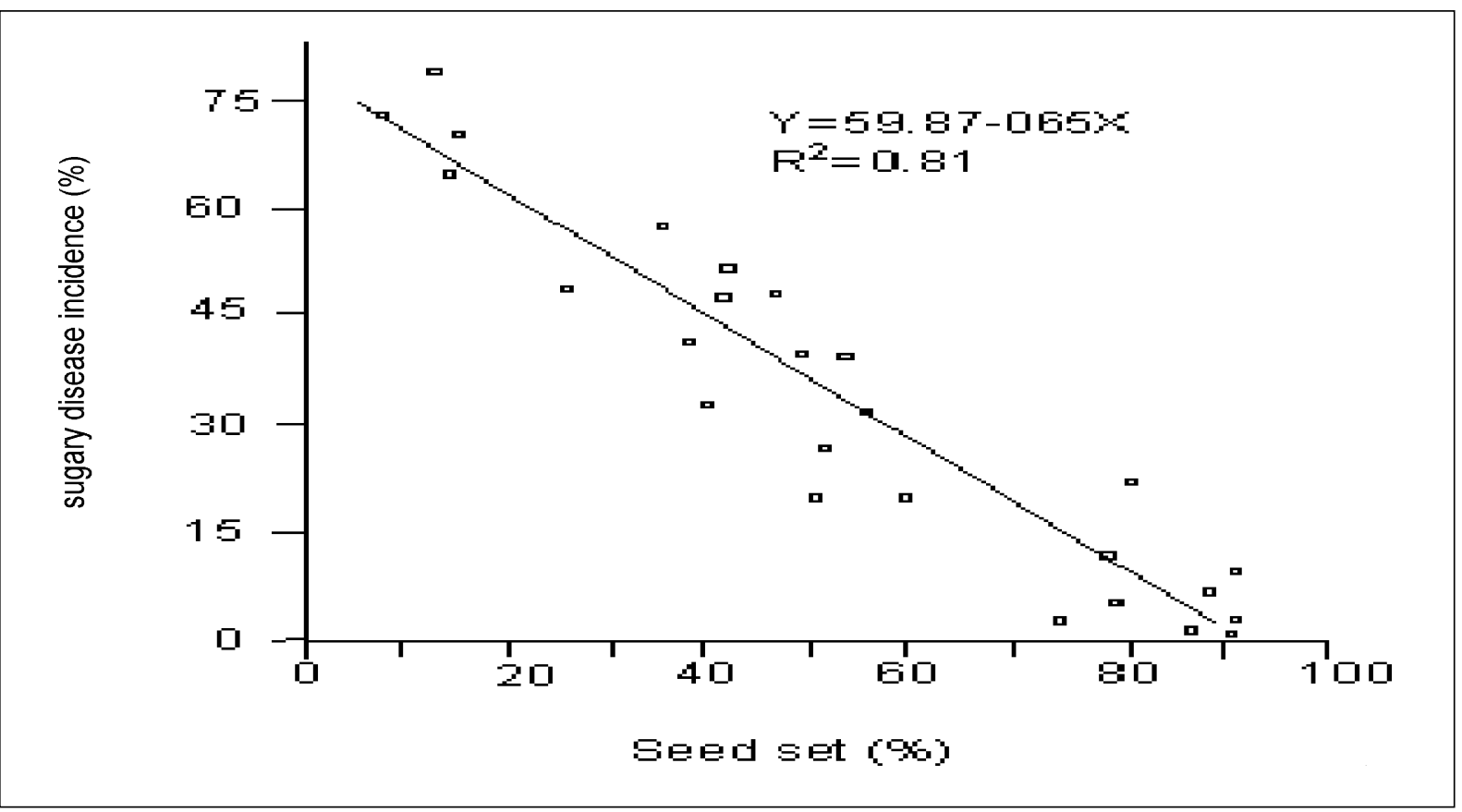

Figure 3 - Relationship between seed set at male-fertile sorghum genotypes and sugary disease incidence caused by Claviceps africana (\%)

before being excluded as a potentially exploitable heritable character. Chemically induced male sterility may help to explore gynoecial susceptibility in sorghum genotypes that naturally escape sugary disease when grown in their native latitude or when induced to flower in more convenient experimental environments.

The response of the $\mathrm{F}: \mathrm{S}$ ratio to minimum air temperatures experienced three to four weeks prior to flowering was quantitative. The close relationship between these two variables suggests that preflowering cold stress is the primary factor to predispose sorghum to sugary disease, a trend also shown by MCLAREN \& WEHNER(1992).

Table 2 - Seed formation at grain maturity in sorghum hybrids panicles covered with pollination bags for two sowing periods (mid November and mid December) during the 2001/02 growing season.

\begin{tabular}{ccc}
\hline hybrids & 1st sowing period & 2nd sowing period \\
\cline { 2 - 3 } & seed formation (\%) & seed formation (\%) \\
\hline BR 600 & 95 & 96 \\
BR 700 & 90 & 92 \\
BR 701 & 97 & 95 \\
BR 800 & 89 & 91 \\
\hline
\end{tabular}

The results of this study, despite of difference between the critical stage prior to flowering (three to four weeks) and the average night temperature (lower than $15^{\circ} \mathrm{C}$ ), confirmed the findings of BROOKING (1976 and 1979), MCLAREN \& WEHNER (1992) and FREDERICKSON et al. (1994) who demonstrated that low, pre-flowering night temperatures $\left(25 / 10^{\circ} \mathrm{C}\right.$ day/night regime) during the microsporogenesis could induce sterility in sorghum by reducing pollen viability.

The slower $\mathrm{F}: \mathrm{S}$ ratio response to temperature changes in BR 701 and BR 800 hybrids is an indication that selection of sorghum genotypes for cold resistance with respect to pollen viability could assist in the control of sugary disease in commercial fields. Breeding and selection for low temperature tolerance with respect to pollen viability must be initiated in the local sorghum program and tolerant lines should contribute towards reducing the risk of sugary disease epidemics.

\section{CONCLUSION}

The relationship between pre-flowering climatic conditions and sugary disease incidence in sorghum in two different periods of sowing indicated that low temperatures three to four weeks prior to flowering increase susceptibility to the disease. Average temperatures lower than $15^{\circ} \mathrm{C}$ during the 
critical period result in male-fertile genotypes being as susceptible as male-sterile genotypes. The reduction in the rate of pollination or pollen viability increases sugary disease susceptibility in male-fertile genotypes.

\section{ACKNOWELEDGEMENTS}

The authors wish to thanks the UDESC fellowship program and CAV/UDESC experimental facilities.

\section{REFERENCES}

BOGO, A. Biochemical physiopathology of some ergot fungi and other honeydew-producing plant parasites. 2001. 141f. Thesis (PhD on Plant Pathology and Biochemistry) - Imperial College of Science, Technology and Medicine), London, UK.

BROOKING, I.R. Male sterility in Sorghum bicolor (L.) Moench induced by low night temperature. I. Timing of the stage of sensitivity. Australian Journal Plant Physiology, v.3, p.589-596, 1976.

BROOKING, I.R. Male sterility in Sorghum bicolor (L.) Moench induced by low night temperature. II. Genotypic differences in susceptibility. Australian Journal Plant Physiology, v.6, p.143-147, 1979.

FREDERICKSON, D.E. et al. Claviceps africana sp. nov.: the distinctive ergot pathogen of sorghum in Africa. Mycological Research, v.95, p.1101-1107, 1991.

FREDERICKSON, D.E. et al. Susceptibility to ergot in Zimbabwe of sorghums that remained uninfected in their native climates in Ethiopia and Rwanda. Plant Pathology, v.43, p.27-32, 1994.

LOVELESS, A.R. C. fusiformis sp. nov., the causal agent of agalactia of sows. Trans British Mycological Society v.50, p.13-18, 1967.

McLAREN, N.W.; WEHNER, F.C. Relationship between climatic variables during early flowering of sorghum and the incidence of sugary disease caused by Sphacelia sorghi. Journal of Phytopathology, v.130, p.82-88, 1990.

McLAREN, N.W.; WEHNER, F.C. Pre-flowering low temperature predisposition of sorghum to sugary disease (Claviceps africana). Journal of Phytopathology, v.135, p.328-334, 1992.

REIS, E.M. et al. First report in the Americas of sorghum ergot disease, caused by a pathogen diagnosed as $\boldsymbol{C}$. africana. Plant Disease, v.80, p.463, 1996.

THAKUR, R. P.; WILLIANS, R. J. Pollination effects on pearl millet ergot. Phytopathology, v. 70, p. 80-84, 1980.

THAKUR, R.P.; RAO, V.P. Control of ergot in pearl millet through pollen management. Annual Applied Biology, v.103, p.31-36, 1983.

WATKINS, J.E.; LITTLEFIELD, L.J. Relationship of anthesis in Waldron wheat to infection by Claviceps purpurea. Trans British Mycological Society v.66, p.362-363, 1976.

WILLINGALE, J.P. et al. Post-pollination stigmatic constriction, the basis of ergot resistance in selected lines of pearl millet. Phytopathology, v.76, p.536-539, 1986. 